\title{
Investigating different factors influencing job satisfaction: A case study of cement industry
}

\author{
Mina Shirvani ${ }^{a^{*}}$, Asghar Mohammadi ${ }^{\mathrm{b}}$, Mohammad Reza Iravani ${ }^{\mathrm{c}}$, Saeed Yousef Pour ${ }^{\mathrm{d}}$, Allahyar \\ Arabmomeni $^{\mathrm{e}}$, Shirin Mirhaj ${ }^{\mathrm{f}}$ and Akram Fakhri Fakhramini ${ }^{\mathrm{g}}$
}

\begin{abstract}
${ }^{a}$ MA Student, Department of Sociology, Dehaghan Branch, Islamic Azad University, Dehaghan, Iran
${ }^{b}$ Department of Sociology, Dehaghan Branch, Islamic Azad University, Isfahan, Iran

${ }^{c}$ Department of Social Work, Islamic Azad University Khomeinishahr Branch, Khomeinishahr, Iran

${ }^{d}$ Professional veterinary doctor, director environment of Chahar Mahal Bakhtiari, Iran

${ }^{e}$ Department of Human Science, University of Khomeinishahr, Khomeinishahr, Iran.

${ }^{f}$ M.A.in General Psychology, Science and Research Branch Islamic Azad University West Azerbaijan Faculty of Humanities Department of Psychology ,

Uremia. Iran

${ }^{g}$ MA Student, Department of Sociology, Dehaghan Branch, Islamic Azad University, Dehaghan, Iran

\section{CH R O N I C L E A B S T R A C T}

Article history:

Received May 18, 2013

Received in revised format

12 August 2013

Accepted 5 September 2013

Available online

September 72013

Keywords:

Cement industry

Job satisfaction plays an important role on increasing business productivity and efficiency. This paper presents an empirical investigation to study the relationship between job satisfaction and employees' personal characteristics including gender, marital status, etc. The proposed study designs a questionnaire and distributes it among 244 out of 800 employees who worked for cement industry in Iran. The data are analyzed using different statistical tests such as t-student and analysis of variance. The results indicate that while there was not any meaningful relationship between gender and job satisfaction there was some meaningful relationship between marital status and job satisfaction.
\end{abstract}

Job satisfaction

Marital status

Gender

\section{Introduction}

During the past few years, there have been different studies on relationship between personal characteristics and job satisfaction (Herzberg 2003). Iravani (2011), for instance, reported that there were some positive relationships between job satisfaction (Seal \& Knight, 1988) and other factors including wage increase, psychological needs, physical equipment, entertainment equipment and work-team. Khorshidifar and Abedia (2011) performed an empirical study on the effect of stress on the relationship between locus of control and job satisfaction and job performance. They reported that stress was on average level for the dominant locos of control factors and job satisfaction and 
employee performance were in relatively high level. They also reported that there were four important factors of role of ambiguity, quantitative overload, career development and handling other workers' responsibilities played important role on job satisfaction and managing career development had important effect on the performance of accountants. Iravani et al. (2013), in other investigation, investigated the impact of marital status as well as educational background on job satisfaction among university employees. The survey detected that there was no difference between female and male employees in terms of job satisfaction, marital status had no significance on job satisfaction.

Khodaei et al. (2013) studied the effect of social capital on job satisfaction and citizenship behavior among 240 employees who work for Allameh Tabataba'i University in Iran. The results of the survey indicated that social capital positively influenced on both mentioned variables. Boroumand and Baghbaan Saad Abaadi (2013) measured the impacts of five factors including work conditions, pay, promotion, supervisor and co-worker on job satisfaction among 130 employees who worked for one of Iranian transmission electricity in Iran and the results of the survey indicated that all employees satisfied from their job conditions.

Heidarzadeh Hanzaee and Mirvaisi (2013) performed a survey on effect of emotional intelligence (EI), organizational citizenship behaviors (OCB) and job satisfaction on employees' performance in Iranian hotel industry. The results of the survey confirmed all the proposed hypotheses of this survey except the one, which was associated with the relationship between OCB on EP. Therefore, EI had positive influences on JS, OCB and EP in Iranian hotel industry.

Baseri (2012) performed an investigation on job satisfaction in accounting and auditing institutions of commercial companies. The primary objective of this study was to investigate the job satisfaction of auditors of audit organizations in comparison to accountants in Business enterprise. In addition, the author tried to analyze the effective factors on job satisfaction in two groups to point to essential guidelines and decrease the job quit in this part of society and increase the efficiency of human resource, even very little. They survey reported that range of dissatisfaction among auditors was more than accountants were. Having too much stress may be another important factor to reduce job satisfaction.

Iravani et al. (2012) performed an empirical survey to measure the effect of stress among people with different gender and marital status in a hydropower unit located in city of Esfahan, Iran. The study performed the survey among all 81 people who were working for customer service section of this unit. The results indicated that gender had no meaningful effect on creating stress among employees who worked for this hydro plant except difficulty of job conditions. The other findings of this survey was that stress posed from management team had different effects on employees with different marital status but there were no meaningful differences between married and single couples in terms of other factors posing stress such as unsuitable working conditions, fear of job stability or difficulty of job conditions.

According to Khodaei Valahzaghard et al. (2012), one of the necessary functions of human resource management is to take care of skilled employees. The process can be divided into two categories: first category includes various activities such as having health and safety in working centers, performing healthy and sport programs and some other similar activities to save and improve employees' physical characteristics. The second group includes other important issues normally called benefit packages, which incorporates good health insurance and retiring plans. Whenever an organization provides good benefit package and supporting programs, there is a better job satisfaction among employee.

Khodaei Valahzaghard et al. (2012) investigated the effects of related services to support employee to reach job satisfaction and employee activities in banking industry and the results showed that employees were relatively satisfied from the benefit package of the bank and they were relatively happy on working for such organization. 
Tajzadeh-Namin (2012) considered the effects of layoff on job satisfaction and commitment among the remaining employees of a detergent producer unit. The results indicated that a good supportive program including wage increase, family support, health care plans, etc. could substantially improve employee long-term commitments and it could lead to job satisfaction.

There are some cases where a mass layoff could influence firms, significantly. Mckee-Ryan and Kinicki (2002) stated that a mass layoff not only hurt people who lose their jobs but also it could have some special social consequences. An immediate layoff decision is to anticipate the remaining workers to work harder and produce more products, which would put more pressure and increase their working stress (McKinley et al., 1995).

The primary objective of layoff could be to increase profitability through reducing direct payment but the layoff could lead to opposite results since workers could not work as well as they used to do (Rigby, 2002). Any possible resistance on behalf of the employees could initiate such negative consequences (Beam, 1997). According to Millward and Brewerton (2002), workers believe terminating a permanent contract offends them and they expect managers to be faithful to their longterm contracts. Shah (2000) reports that any successful downsizing program must be accompanied with better benefit packages, which includes better features.

\section{The proposed study}

This paper presents an empirical investigation to study the relationship between job satisfaction and employees' personal characteristics including gender, marital status, etc. The proposed study implemented among employees who work for one of Iranian Cement unit. There were 800 employees working for this unit and the sample size is calculated as follows,

$$
n=\frac{N \times z_{\alpha / 2}^{2} \times p \times q}{\varepsilon^{2} \times(N-1)+z_{\alpha / 2}^{2} \times p \times q},
$$

where $N$ is the population size, $p=1-q$ represents the yes/no categories, $z_{\alpha / 2}$ is CDF of normal distribution and finally $\varepsilon$ is the error term. Since we have $p=0.5, z_{\alpha / 2}=1.96$ and $N=800$, the number of sample size is calculated as $n=246$. The proposed study designs a questionnaire in Likert scale (Likert, 1932), distributes it among employees of this business unit and using some statistical test, we examine the hypotheses of the survey.

There are two main hypotheses associated with the study of this paper as follows,

1. There is a meaningful relationship between gender and job satisfaction.

2. There is a meaningful relationship between marital status and job satisfaction.

\subsection{Personal characteristics of the participants}

We first present details of our survey on personal characteristics of the participants. Fig. 1 demonstrates the results of survey, 


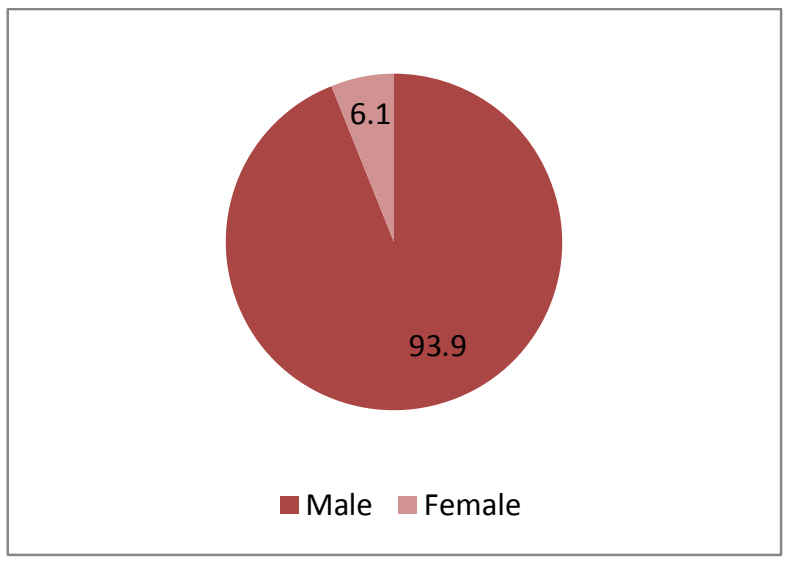

Percentage of gender

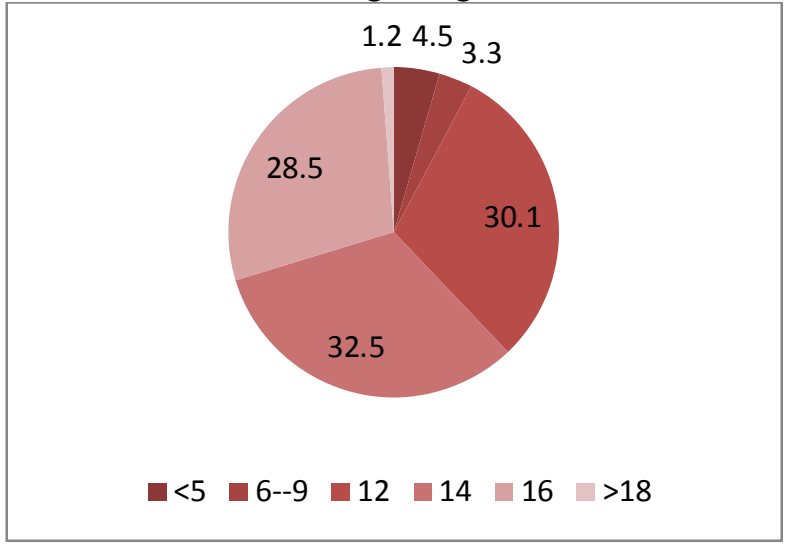

Years of education

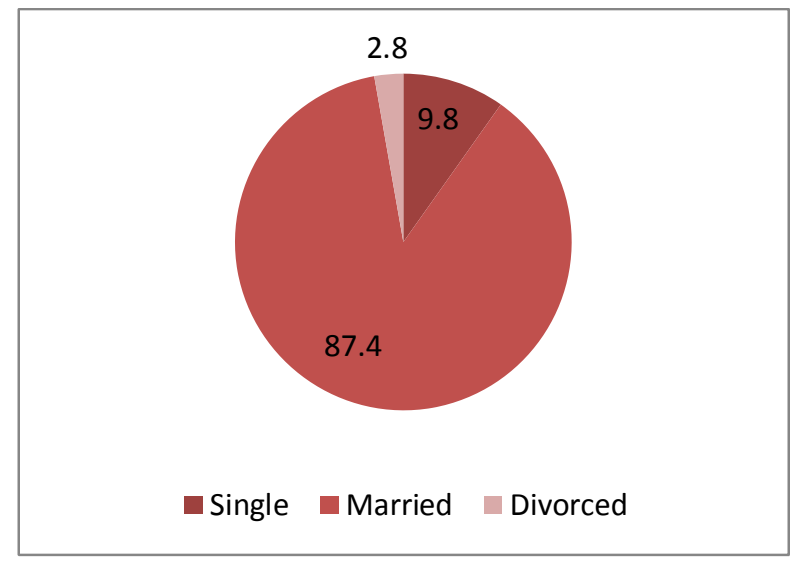

Percentage of marital status

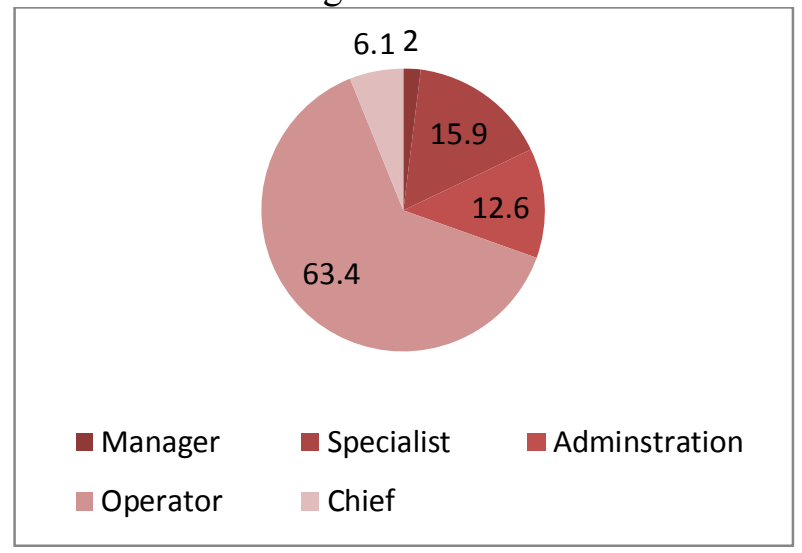

Percentage of specialty

Fig. 1. Personal characteristics of the participants

As we can observe from the results of Fig. 1, 93.9\% of the participants are male and $87.4 \%$ of them were married.

\section{The results}

In this section, we present details of our survey on testing two hypotheses of this survey.

\subsection{The relationship between gender and job satisfaction}

The first hypothesis of this survey is associated with the relationship between gender and job satisfaction. Table 1 shows basic statistics of our survey.

\section{Table 1}

The results of surveying between gender and job satisfaction

\begin{tabular}{lcccc}
\hline Gender & $\mathrm{N}$ & Mean & Std. Deviation & Std. Error Mean \\
\hline Male & 231 & 2.65 & .554 & .036 \\
Female & 15 & 2.60 & .632 & .163 \\
\hline
\end{tabular}

Applying t-test between two groups yields t-value $=0.331 \mathrm{P}$-value $=0.358$, which means there is no meaningful relationship between gender and job satisfaction. 


\subsection{The relationship between marital status and job satisfaction}

The second hypothesis of this survey is associated with the relationship between marital status and job satisfaction. Table 2 demonstrates some basic statistics of our survey.

\section{Table 2}

The results of surveying between marital status and job satisfaction

\begin{tabular}{lcccc}
\hline Gender & $\mathrm{N}$ & Mean & Std. Deviation & Std. Error Mean \\
\hline Single & 24 & 2.25 & .442 & .090 \\
Married & 215 & 2.70 & .553 & .038 \\
\hline
\end{tabular}

Applying t-test between two groups yields $\mathrm{t}$-value $=-3.832 \mathrm{P}$-value $=0.057$, which means there is a meaningful relationship between marital status and job satisfaction.

\section{Conclusion}

In this paper, we have presented an empirical investigation to study the relationship between personal characteristics and job satisfaction in one of Iranian Cement industries. The study has detected no relationship between gender and job satisfaction and the results are consistent with Iravani et al. (2013). Iravani et al. (2012) performed an empirical survey to measure the effect of stress among people with different gender and reported no difference among employees with different genders. The study also investigated the effect of marital status on job satisfaction and found some differences between single and married employees in this organization.

\section{References}

Baseri, S. (2012). An investigation on of job satisfaction in accounting and auditing institutions of commercial companies. Management Science Letters, 3(2), 638-688.

Beam, H.H. (1997). Survivors: how to keep your best people on board after downsizing. The Academy of Management Executive, 11(2), 92-94.

Boroumand, Z., \& Baghbaan Saad Abaadi, M. (2013). An investigation on factors influencing job satisfaction: A case study of electricity distribution firm. Management Science Letters, 3(7), 18791884.

Heidarzadeh Hanzaee, K., \& Mirvaisi, M. (2013). A survey on impact of emotional intelligence, organizational citizenship behaviors and job satisfaction on employees' performance in Iranian hotel industry. Management Science Letters, 3(5), 1395-1402.

Herzberg, F. (2003) One more time: How do you motivate employees?. Harvard Business Review, 81(1), 87-95.

Iravani (2011). A social work study on job satisfaction. Management Science Letters, 2(4), 13971402.

Iravani, M.R., Iravani, G., Khorvash, M., \& Mosavi, S.E. (2012). A social work study on measuring the impact of gender and marital status on stress: A case study of hydro-power employees. Management Science Letters, 2(6), 2097-2102.

Iravani, M.R., Hosseini, S.S., Rajabi, M., Fakhri Fakhramini, A., Mirhaj, S., \& Shirvani, M. (2013). A social work study on the effect of gender and marital status on job satisfaction. Management Science Letters, 3(8), 2285-2288.

Khodaei Valahzaghard, M., Afzali, F., \& Khodaei Valahzaghard, S. (2012). An empirical study on the effects of human resource supporting strategies on job satisfaction. Management Science Letters, 2(5), 1535-1542.

Khodaei, R., Khodaei Valehzaghard, H., \& Anvar, H. (2013). A study on the effect of social capital on job satisfaction and citizenship behaviour. Management Science Letters, 3(7), 1873-1878. 
Khorshidifar, M., \& Abedia, A. (2011). An empirical study on the impact of stress on the relationship between locus of control and job satisfaction and job performance. Management Science Letters, 1(4), 511-516.

Likert, R. (1932). A Technique for the Measurement of Attitudes. Archives of Psychology, 140, 1-55.

Mckee-Ryan, F.M., \& Kinicki, A.J. (2002). Coping with job loss: a life-facet perspective. International Review of Industrial and Organizational Psychology, 17, 1-29.

McKinley, W., Sanchez, C.M., \& Schick, A.G. (1995). Organizational downsizing: constraining, cloning, learning. The Academy of Management Executive, 9(3), 32-44.

Millward, L.J., \& Brewerton, P.M. (2002). Psychological contracts: employee relations for the twenty-first century?. International Review of Industrial and Organizational Psychology, 15, 161.

Rigby, D. (2002). Look before you lay off. Harvard Business Review, 80(4), 20-21.

Seal, F.E., \& Knight, P.A. (1988). Industrial Organizational Psychology: Science \& Practice, Brooks.Cole, Pacific Grove of California.

Shah, P.P. (2000). Network destruction: the structural implications of downsizing. Academy of Management Journal, 43(1), 101-112.

Tajzadeh-Namin, A. (2012). An empirical study on measuring the effect of layoff on job satisfaction and employee commitment: A case study of detergent producer unit. Management Science Letters, 2(1), 213-220. 